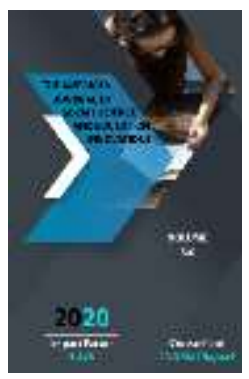

\title{
Content Of Recreation Geography And Recreation Possibilities Of Turkestan-Nurota Mountain System
}

\author{
Sakarbek Kholmurodov \\ Researcher Of Tashkent State Pedagogical University Named After Nizami. Tashkent City, \\ Uzbekistan
}

Journal Website:

http://usajournalshub.c

om/index,php/tajssei

Copyright: Original

content from this work may be used under the

terms of the creative

commons attributes

4.0 licence.

\section{ABSTRACT}

This article analyzes the content of the geography of recreation and the recreational potential of the landscapes of the Turkestan-Nurata mountain range.

\section{KEYWORDS}

Recreation, tourism, ecological tourism, journey, travel, recreational geography, recreational load, geosystem.

\section{INTRODUCTION}

Recreation (recreational - French - leisure, relaxation, recreation - rest in Polish language, recreation in Latin) - this includes: 1) holidays, vocation, school breaks; 2) a separate building for recreation in the educational institution; 3) Restoration of a person's labor force in the process of labor (Russian Encyclopedia Dictionary. M., 2000, Volume 2). In addition, N.F.Reims (1994) indicates the health of human and ability to work is not on the place of residence, but on organized or unregistered tourist trips, or on vacation, with special recreational facilities (sanatorium, rest homes, etc.). From an alternative point of view, this approach can be understood as when any recreational activity is regarded as any time and place.

National Tourism Policy Research Center of the USA explains the terms of "trip or travel", "tourism" and "recreation" in the followings:

1. Trip or travel is a way of moving from their permanent place of residence to other countries or to other parts of their 
own country, with the exception of any form of employment.

2. Tourism - a synonym of the terms of "trip or travel".

3. Recreation is the ability of consciously use of persons' free time. Recreation may be passive and can be either active or separated and as groups.

In our opinion, it is important to understand for people that it is the restoration of health in free time of people and people can enjoy a healthy lifestyle at places of nature, in order to restore their health. With these aspects, it is similar to ecotourism, closer to one another, and the basis for it. It's no secret that in the last few decades, global ecological tourism is becoming widespread, evolving and popular. Therefore, in special literature ecotourism divided into:

- Soft tourism;

- Mountain tourism, natural tourism and wild natural tourism;

- Green tourism, adventure tourism, rural tourism;

- Ecologically or ecotourism.

The outstanding tourism theorist, Y.Krippendorf, described ecological tourism as "peaceful or calming tourism" and described it as "providing opportunities for physical and spiritual leisure activities in landscapes, as well as local populations' longterm interests, as well as recreational and recreational opportunities (Mose J. 1988. Bd.6.S.34).

Thus, it is desirable that these similarities be always considered and respected in the geographical study of recreational and ecological tourism.

First attention was paid to the issue of territorial organization of the population holiday, as a result of observing the irrational use in nature that the rest of the recreation of the rest of the forest in the climatic zones of
Klyazma boarding house near Moscow in 1966-1967. Indeed, due to the prolonged leisure time, increasing the incomes and the cultural level of the population, the recreation in the city outside was also a regular one. It is clear that this process involves various subjects such as economics, sociology, psychology, medical and biological sciences; it has had a considerable impact on the development of geography, which at present time in an independent geographical area we can see a geography of recreation. At the early stages of geographical research in recreational activities, particular attention was paid to tourism development in some parts of the world, the impact of foreign tourism on the balance of payments, and the role of tourism in a particular form of population migration. Subsequently, the scope of the tourism industry's relationship with other sectors of human activity was also moderated. A comprehensive study of the problems of recreation in geography was studied firstly by community of natural and economic geographical divisions of the Geographical Institute of the Academy of Sciences of the former Soviet Union. Since the mid-6os of the last century, leadership in development of recreational geography has moved to Moscow State University named after M.Lomonosov.

One of the most practical aspects of Landscape science is the organization of outdoor recreation or recreational activities (A.J.Isachenko, 1979, p. 178). The research object of the recreational geography is the regional recreation systems (RRS), which includes recreational, natural, personnel service and management organizations (V.Preobrajensky, Yu.A.Vedenin, 1971). Nowadays, recreational geography is the science of the territorial organization of recreational activities of people. Modern recreational geography includes the concept of a research object with complex, social, 
technique and natural components. They have made a significant impetus to the concept of territorial recreation systems in the former Soviet Union.

The subject of research in the recreational geography is the study of the characteristic features of people's character and learning the laws of space and the placement of recreational objects.

Complex tasks of the recreational geography (including other organization not geographical service providers and other issues) are the study of the recreational potential of the geochemical systems that are directly related to the practical landscape science and to their recreational evaluation and the effect of recreational (recreational load) (A.G.Isachenko, 1979, pp. 180-181).

From the foregoing analysis, it is clear that recreatio is the basis of tourism, especially ecological and medical tourism. One such recreation area is Turkestan-Nurota mountain and foothill landscapes. First of all, this territory is located in the central part of the Republic of Uzbekistan, with the favorable geographical location of railways and car ways across the country.

Relief is mountainous and separates the Turkiston line from Shahristan (3351 m) to the west of the Sangzor River valley, in the south Chumqortog Ridge, and in the north to Molguzar Mountains. The Molguzar Mountain was separated from the Nurota Range through Ilonotti Tributary. The Turkestan Ridge, with the highest peaks reaching 4,000 $\mathrm{m}$, and it is located at 3,000 $\mathrm{m}$ higher in Chumqortag and there are high peaks more than $2600 \mathrm{~m}$ above in Molguzar.
The Nurota Ridge is a logical north-western extension of Molguzar with a length of 200 $\mathrm{km}$ and a width of $75 \mathrm{~km}$. The highest point is the Hayotboshi peak with the height $2165 \mathrm{~m}$, and the eastern part of the hill is called Kuytosh Mountain.

In the lower parts on the recreation, the climate is slightly mild - the summer is hot and dry, and the winter is not cold (the average January temperature is $0.2^{\circ} \mathrm{C}$, the mountain peaks $-11^{\circ} \mathrm{C}$, in the July is about $25-26^{\circ} \mathrm{C}$ ).

Besides from Sangzor and Zaamin, which receives water from the Turkestan Mountains, more than 70 bourns flow. From the north of the Nurata Ridge, 45 bourns begin to flow, with over 30 bourns flow from the southern slopes. These bourns and rivers are beautiful and unique. In addition, river-bourns are rich to springs. For example, in the Bosmandisoy basin, 130 of springs were found, in the Kattasoy basin - 170, in Shahriston basin more than 220 springs. Also important objects of recreation can be Jizzakh, Zomin, Tusunsay, Kattasoy reservoirs and Tuyatortar canal.

The thickness of fir-trees at the altitudes of 1800 (2000) up to $3000 \mathrm{~m}$ at the TurkestanRange is of considerable importance in ensuring the air-purification. Besides of the firtree, pistachio, almonds and other plants grow in arid slopes of the Nurata Ridge. The parts of the area above $3000 \mathrm{~m}$ are occupied by subalpine meadows.

In general, you can see the following landscapes:

Typical gray ground lyons with thick brown plains consisting of Poa bulbosae and other plants covering the middle part of the Sangzor valley;

- Brown soil in lower slopes of Turkistan and Morguzar mountains, with almond and Agropyron sp.; 
- Fir-tree with dark mountain - forest and brown soil mountains with 1400-2800 m height in Turkistan and Molguzar mountains;

- Alpine meadows in the highest parts of the Turkestan range (rocky, snow-covered areas);

- Agropyron sp. and typical grassy in typical gray and brown soils in average height of Nurota, Koytosh Mountains;

- Artemesia sp. and xerophytes with shrubs in the Nurata Mountains (Baratov P. 1996, pp. 232-233).

The Turkestan-Nurata Mountains are rich in diversity of the animal world. Besides, the region has its own mineral resources. The point is the rational use and protection of available resources.

Because the existing opportunities play a role to attract vacationers in the region.

\section{REFERENCES}

1. Baratov P. The natural geography of Uzbekistan. T: Teacher, 1996.- p. 246.

2. Geography today. Collection. -M.: Knowledge, 1984. - p.128.

3. Isachenko A.G. Geography today: A guide for teachers. -M.: Enlightenment, 1979. p. 192.

4. Kvartalnov V.A. Tourism. -M.: Finance and Statistics, 2003. - p. 309.

5. Kuskov A.S., Golubeva V.L., Odinsova T.N. Rekreational geography: Educational methodical complex. -M.: Flinta, 2005. p. 315.

6. Mose J.: Tourisimus im National park Hohe Taurn. Vechtaer Arbeiten zur Geographe und Regional wissenschaft. 1988. Bd.6.S.34.

7. Preobrazhensky V.S, Vedenin Yu.A. Geography and rest. -M.: Science, 1971. p. 48.
8. Preobrazhensky V.S. Search in geography: Book for the teacher. $-M$.: Enlightenment, 1986. -p. 224.

9. Reimers N.F. Ecology.- M.: Russia is young, 1994.

10. Theoretical foundations of recreational geography. -M.: Science. 1975. 